\title{
Electron Transfer and CO Addition to Polynitrido Cobalt Carbonyl Clusters: Parallel Pathways for Conversion of the $\left[\mathrm{CO}_{10} \mathrm{~N}_{2}(\mathrm{CO})_{19}\right]^{4-}$ Anion to the Novel $\left[\mathrm{CO}_{11} \mathrm{~N}_{2}(\mathrm{CO})_{21}\right]^{3-}$ Anion
}

\author{
Alessandro Fumagalli, ${ }^{*},{ }^{\dagger}$ Paola Ulivieri, ${ }^{\dagger}$ Michela Costa,${ }^{\dagger}$ Ornella Crispu, ${ }^{\dagger}$ Roberto Della Pergola, ${ }^{\ddagger}$ \\ Fabrizia Fabrizi de Biani, ${ }^{\S}$ Franco Laschi, $\$$ Piero Zanello, ${ }^{\S}$ Piero Macchi," and Angelo Sironi ${ }^{\star, \|}$ \\ Dipartimento di Biologia Strutturale e Funzionale dell'Università degli Studi dell'Insubria, \\ Via J. H. Dunant 3, 21100 Varese, Italy, Dipartimento di Scienze dell'Ambiente e del Territorio \\ dell'Università di Milano-Bicocca, Piazza della Scienza 1, 20126 Milano, Italy, Dipartimento di \\ Chimica dell'Università di Siena, Via Aldo Moro, 53100 Siena, Italy, and Dipartimento di \\ Chimica Strutturale e Stereochimica Inorganica dell'Università di Milano, Via G. Venezian 21, \\ 20133 Milano, Italy, and Istituto di Scienze e Tecnologie Molecolari (ISTM)-CNR, via Golgi 19, \\ 20133 Milano, Italy
}

Received September 30, 2003

The redox aptitude of the dinitrido anion $\left[\mathrm{CO}_{10} \mathrm{~N}_{2}(\mathrm{CO})_{19}\right]^{4-}$ has been tested from both chemical and electrochemical points of view, together with its reactivity toward $\mathrm{CO}$ that induces disproportionation. In any case, through a remarkable overlapping of intermediate steps, the new anion $\left[\mathrm{CO}_{11} \mathrm{~N}_{2}(\mathrm{CO})_{21}\right]^{3-}(4)$ is eventually obtained. A detailed study of the pathways to 4 allowed the identification of three labile intermediates by their characteristic IR spectra as well as their electrochemical and paramagnetic properties. The unprecedented structure of trianion 4 has been studied in details in two different crystalline salts.

\section{Introduction}

Interstitial or semiinterstitial atoms of the main group elements (C, N, P, etc.) play an essential role in the stabilization of high-nuclearity metal carbonyl clusters not only because they can contribute to the number of cluster valence electrons with no sterical requirements on the cluster surface but also because they can modify the bonding character of the frontier molecular orbitals. ${ }^{1,2}$ In this respect, nitrido species are particularly interesting, since nitrogen atoms may donate up to five electrons and also show a distinctive aptitude toward unusual stereochemistries and coordination numbers within the interstitial cavity, thus resulting in singular cluster shapes and uncommon electron-

\footnotetext{
* To whom correspondence should be addressed. E-mail: alessandro.fumagalli@uninsubria.it (A.F.); angelo.sironi@istm.cnr.it (A.S.). Tel: +390332 421548 (A.F.); +3902 50314448 (A.S.). Fax: +39 0332421554 (A.F.); +3902 50314454 (A.S.).

† Università dell'Insubria.

†niversità di Milano-Bicocca.

$\S$ Università di Siena.

"Università di Milano and CNR.

(1) Collini, D.; Femoni, C.; Iapalucci, M. C.; Longoni, G.; Svensson, P. H.; Zanello, P. Angew. Chem., Int. Ed. 2002, 41, 3685-3688.

(2) Albano, V. G.; Demartin, F.; Iapalucci, M. C.; Laschi, F.; Longoni, G.; Sironi, A.; Zanello, P. J. Chem. Soc., Dalton Trans. 1991, 739.
}

transfer properties. ${ }^{3,4}$ Several homo- and heterometallic carbonyl clusters containing one interstitial nitrogen atom have been synthesized, but so far quite a few polynitrido species have been reported. Namely, the high-nuclearity anions containing two, three, or four nitrogen atoms are $\left[\mathrm{Co}_{10} \mathrm{~N}_{2}(\mathrm{CO})_{19}\right]^{4-},{ }^{5}\left[\mathrm{Co}_{13} \mathrm{~N}_{2}(\mathrm{CO})_{24}\right]^{3-}, 6\left[\mathrm{Co}_{14} \mathrm{~N}_{3}(\mathrm{CO})_{26}\right]^{3-,}$, $\left[\mathrm{Rh}_{12} \mathrm{~N}_{2}(\mathrm{CO})_{23} \mathrm{H}\right]^{3-,}, 8\left[\mathrm{Rh}_{14} \mathrm{~N}_{2}(\mathrm{CO})_{25}\right]^{2-},{ }^{2}\left[\mathrm{Rh}_{23} \mathrm{~N}_{4}(\mathrm{CO})_{38}\right]^{3-},{ }^{10}$ and $\left[\mathrm{Rh}_{28} \mathrm{~N}_{4}(\mathrm{CO})_{41} \mathrm{H}_{x}\right]^{4-} .{ }^{11}$ They have been generally derived

(3) Fumagalli, A.; Della Pergola, R. Metal Clusters in Chemistry; Braunstein, Oro, Raithby, Eds.; Wiley-VCH: New York, 1999; pp 323-347.

(4) Zanello, P. Physical Organometallic Chemistry. Vol. 3. Unusual Structures and Physical Properties in Organometallic Chemistry; Gielen, M., Willem, R., Wrackmeyer, B., Eds.; John Wiley: Chichester, U.K., 2002; pp 1-49.

(5) Fumagalli, A.; Martinengo, S.; Tasselli, M.; Ciani, G.; Macchi, P.; Sironi, A. Inorg. Chem. 1998, 37, 2826.

(6) Fumagalli, A.; Costa, M.; Della Pergola, R.; Zanello, P.; Fabrizi de Biani, F.; Macchi, P.; Sironi, A. Inorg. Chim. Acta 2003, 350, 187192.

(7) Martinengo, S.; Ciani, G.; Sironi, A. J. Organomet. Chem. 1988, 358 , C23.

(8) Martinengo, S.; Ciani, G.; Sironi, A. J. Chem. Soc., Chem. Commun. 1986, 1742

(9) Martinengo, S.; Ciani, G.; Sironi, A. J. Chem. Soc., Chem. Commun $1991,26$.

(10) Martinengo, S.; Ciani, G.; Sironi, A. J. Chem. Soc., Chem. Commun. 1992, 1405 .

Inorganic Chemistry, Vol. 43, №. 6, 20042125 
Fumagalli et al.

Table 1. IR CO-Stretching $\left( \pm 2 \mathrm{~cm}^{-1}\right)$ of the Anions $\mathbf{A}-\mathbf{C}$ and $\left[\mathrm{Co}_{11} \mathrm{~N}_{2}(\mathrm{CO})_{21}\right]^{3-}$ (4)

\begin{tabular}{|c|c|c|c|}
\hline anion & cation, solvent & terminal COs & bridging $\mathrm{COs}$ \\
\hline A & {$\left[\mathrm{NMe}_{4}\right]^{+}, \mathrm{MeCN}$} & $1960 \mathrm{~s}$ & $1803 \mathrm{~m}, 1780 \mathrm{w}$ \\
\hline \multirow[t]{2}{*}{ B } & $\mathrm{Cs}^{+}$, acetone & $1970 \mathrm{~s}, 1949 \mathrm{~ms}$ & $1804 \mathrm{~m}$ \\
\hline & $\mathrm{Cs}^{+}, \mathrm{MeCN}$ & $1973 \mathrm{~s}, 1953 \mathrm{~ms}$ & $1803 \mathrm{~m}, 1779 \mathrm{mw}$ \\
\hline \multirow[t]{4}{*}{$\mathrm{C}$} & $\mathrm{Cs}^{+}$, acetone & $2001 \mathrm{~s}, 1983 \mathrm{~ms}$ & $1836 \mathrm{~m}$ \\
\hline & {$\left[\mathrm{NMe}_{4}\right]^{+}$, acetone } & $2001 \mathrm{~s}$ & $1836 \mathrm{~m}$ \\
\hline & $\mathrm{Cs}^{+}, \mathrm{MeCN}$ & $2003 \mathrm{~s}$ & $1834 \mathrm{~ms}$ \\
\hline & {$\left[\mathrm{NMe}_{4}\right]^{+}, \mathrm{MeCN}$} & $2003 \mathrm{~s}$ & $1835 \mathrm{~m}$ \\
\hline \multirow{3}{*}[\mathrm{Co}_{11}\mathrm{N}_{2}(\mathrm{CO})_{21}]{$^{3-}(\mathbf{4})$} & {$\left[\mathrm{NMe}_{4}\right]^{+}$, acetone } & $1975 \mathrm{~s}, 1931 \mathrm{mw}$ & $1830 \mathrm{sh}, 1822 \mathrm{~ms}, 1813 \mathrm{~m}$ \\
\hline & {$\left[\mathrm{NMe}_{4}\right]^{+}, \mathrm{MeCN}$} & $1978 \mathrm{~s}, 1933 \mathrm{mw}$ & $1831 \mathrm{~m}, 1821 \mathrm{~ms}, 1813 \mathrm{~m}$ \\
\hline & $\mathrm{Cs}^{+}, 2\left[\mathrm{NBu}_{4}\right]^{+}, \mathrm{MeCN}$ & $1978 \mathrm{~s}, 1933 \mathrm{mw}$ & $1831 \mathrm{~m}, 1822 \mathrm{~ms}, 1813 \mathrm{~m}$ \\
\hline
\end{tabular}

from the prototypical trigonal prismatic anions $\left[\mathrm{Co}_{6} \mathrm{~N}(\mathrm{CO})_{15}\right]^{-}$ $(\mathbf{1})^{12}$ and $\left[\mathrm{Rh}_{6} \mathrm{~N}(\mathrm{CO})_{15}\right]^{-, 13}$ respectively. At difference with polycarbido clusters, ${ }^{14,15}$ no $\mathrm{N}-\mathrm{N}$ direct interaction has ever been detected.

To find new examples of high-nuclearity polynitrido species we investigated the reactivity of the $\left[\mathrm{Co}_{10} \mathrm{~N}_{2}(\mathrm{CO})_{19}\right]^{4-}$ (3) anion. Since the cesium salt of this tetraanion is relatively easily produced in high yields, it appeared as the ideal starting material to deal with. The anion is quite reactive toward electrophilic reagents and $\mathrm{CO}$, and this prompted us to study both aspects. As a result, we now report on the new undecanuclear dinitrido cluster anion $\left[\mathrm{Co}_{11} \mathrm{~N}_{2}(\mathrm{CO})_{21}\right]^{3-}(\mathbf{4})$, which shows unprecedented molecular structure.

\section{Result and Discussion}

1. Reactivity of $\left[\mathrm{Co}_{10} \mathrm{~N}_{2}(\mathrm{CO})_{19}\right]^{4-}$. IR monitoring, with application of spectral subtraction techniques, allowed the study of the $\left[\mathrm{Co}_{10} \mathrm{~N}_{2}(\mathrm{CO})_{19}\right]^{4-}$ tetraanion (3) from two points of view, its redox aptitude and the degradation induced by $\mathrm{CO}$, as summarized in Scheme 1. Several one-electron chemical oxidants, such as $\left[\mathrm{C}_{7} \mathrm{H}_{7}\right]^{+},\left[\mathrm{Cp}_{2} \mathrm{Fe}\right]^{+}\left(\mathrm{PF}_{6}{ }^{-}\right.$salts $)$, and $\mathrm{I}_{2}$, have been checked, yielding identical results. Actually, $\left[\mathrm{Co}_{10} \mathrm{~N}_{2}(\mathrm{CO})_{19}\right]^{4-}$ can be titrated by those reagents, the end point being clearly detected by IR spectroscopy (Table 1); the progressive increase of a new species (A in Scheme 1) can be monitored by the disappearance of the bands of the original tetraanion $\mathbf{3}$. Further oxidation of $\mathbf{A}$ does not afford a step as sharp as the previous one in that, before completion of the reaction yielding the $\mathbf{B}$ anion, there is evidence of a third species $\mathbf{C}$, together with some $\left[\mathrm{Co}(\mathrm{CO})_{4}\right]^{-}$. This sequence is consistent with the electrochemical findings (see later on) that show two reversible oxidations (the first of the two corresponding intermediates looking like more stable than the second), followed by a further irreversible step. In any case, an excess of oxidant, or even an excess of mineral acids $\left(\mathrm{H}_{3} \mathrm{PO}_{4}, \mathrm{H}_{2} \mathrm{SO}_{4}\right)$, ultimately affords the only species $\mathbf{C}$, with some $\left[\mathrm{Co}(\mathrm{CO})_{4}\right]^{-}$as a byproduct.

The reaction of the $\left[\mathrm{Co}_{10} \mathrm{~N}_{2}(\mathrm{CO})_{19}\right]^{4-}$ anion with $\mathrm{CO}$ intersects the oxidation sequence. Several steps characterize

(11) Fumagalli, A.; Martinengo, S.; Bernasconi, G.; Ciani, G.; Proserpio, D. M.; Sironi, A. J. Am. Chem. Soc. 1997, 119, 1450.

(12) Martinengo, S.; Ciani, G.; Sironi, A.; Heaton, B. T.; Mason, J. J. Am. Chem. Soc. 1979, 101, 7095.

(13) Bonfichi, R.; Ciani, G.; Sironi, A.; Martinengo, S. J. Chem. Soc., Dalton Trans. 1983, 253.

(14) Albano, V. G.; Braga, D.; Ciani, G.; Martinengo, S. J. Organomet. Chem. 1981, 213, 293.

(15) Martinengo, S.; Noziglia, L.; Fumagalli, A.; Albano, V. G.; Braga, D.; Grepioni, F. J. Chem. Soc., Dalton Trans. 1998, 2493.
Scheme 1. Routes Leading from the Dinitrido $\left[\mathrm{Co}_{10} \mathrm{~N}_{2}(\mathrm{CO})_{19}\right]^{4-}$ Cluster Tetraanion to the $\left[\mathrm{Co}_{6} \mathrm{~N}(\mathrm{CO})_{15}\right]^{-}$Anion, As Obtained by Oxidation or CO-Induced Disproportionation ${ }^{a}$

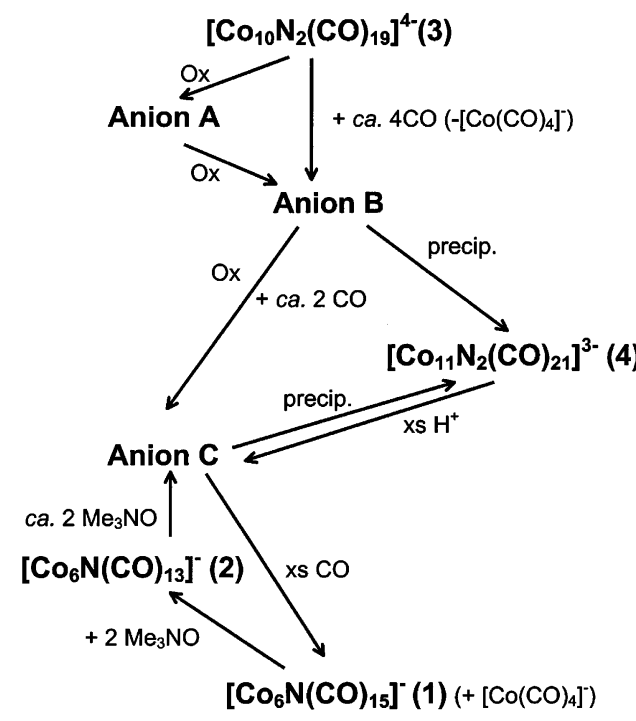

${ }^{a} \mathrm{Ox}=$ elemental iodine, $\mathrm{C}_{7} \mathrm{H}_{7}{ }^{+}$, or $\mathrm{FeCp}_{2}{ }^{+}$; $\mathrm{xs}=$ excess.

this complicate reaction. In fact, an acetone or $\mathrm{MeCN}$ solution of the tetraanion $\mathbf{3}$ (as cesium or $\mathrm{NMe}_{4}{ }^{+}$salt) under nitrogen atmosphere was treated, at room temperature, with several small portions of the gaseous reagent injected, by a gastight syringe, through a rubber septum. In this way, after each addition of $\mathrm{CO}$, allowing a few minutes of stirring for gas-solution equilibration, we could obtain a series of IR spectra, tracking the whole process. After many experiments we got evidence of two metastable intermediate species, the very same anions $\mathbf{B}$ and $\mathbf{C}$, already detected by oxidation. According to Scheme 1, the complete reaction of $\left[\mathrm{Co}_{10} \mathrm{~N}_{2}-\right.$ $\left.(\mathrm{CO})_{19}\right]^{4-}$ to anion $\mathbf{B}$ requires about $4 \mathrm{~mol}$ of $\mathrm{CO}$ (per mol of 3). Considering the side formation of $\left[\mathrm{Co}(\mathrm{CO})_{4}\right]^{-}$, and the higher oxidation state of anion $\mathbf{B}$ (its IR absorption bands are shifted at higher wavenumbers), this reaction can be indeed classified as a disproportionation. At this fairly welldefined step of the reaction, we could even separate anion B (as cesium salt) by precipitation with apolar solvents. However, the oily product obtained proved unstable and further manipulation or attempt of metathesis with bulky cations and/or crystallization invariably resulted in decomposition to the $\left[\mathrm{Co}_{11} \mathrm{~N}_{2}(\mathrm{CO})_{21}\right]^{3-}$ anion (4). If, conversely, $2-3 \mathrm{~mol}$ of $\mathrm{CO}$ is furtherly added, anion $\mathbf{B}$ is decomposed with formation of essentially anion $\mathbf{C}$. However, this second step, which implies formation of some more $\left[\mathrm{Co}(\mathrm{CO})_{4}\right]^{-}$, is not well defined and mixtures are obtained, containing 
Table 2. Formal Electrode Potentials (V, vs SCE) and Peak-to-Peak Separations (mV) for the Redox Changes Exhibited by $\left[\mathrm{Co}{ }_{10} \mathrm{~N}_{2}(\mathrm{CO})_{19}\right]^{4-}$ and $\left[\mathrm{Co}_{11} \mathrm{~N}_{2}(\mathrm{CO})_{21}\right]^{3-}$ in $\mathrm{MeCN}$ Solution

\begin{tabular}{ccccccrcrcr}
\hline complex & $E^{\mathrm{o}^{\prime} / 2-}$ & $\Delta E_{\mathrm{p}}{ }^{a}$ & $E^{\mathrm{o}^{\prime}}{ }_{2-13-}$ & $\Delta E_{\mathrm{p}}{ }^{a}$ & $E^{\mathrm{o}^{\prime}}{ }_{3-/ 4-}$ & $\Delta E_{\mathrm{p}}{ }^{a}$ & $E^{\mathrm{o}^{\prime}}{ }_{4-15-}$ & $\Delta E_{\mathrm{p}}{ }^{a}$ & $E^{\mathrm{o}^{\prime}}{ }_{-16-}$ & $\Delta E_{\mathrm{p}}{ }^{a}$ \\
\hline$\left[\mathrm{Co}_{10} \mathrm{~N}_{2}(\mathrm{CO})_{19}\right]^{4-}$ & $-0.14^{b}$ & & -0.52 & 72 & -0.85 & 74 & -1.72 & 75 & -2.16 & 80 \\
{$\left[\mathrm{Co}_{11} \mathrm{~N}_{2}(\mathrm{CO})_{21}\right]^{3-}$} & $-0.23^{c}$ & 66 & $-0.23^{c}$ & 66 & -1.05 & 117 & -1.47 & 125 & $-2.07^{d}$ &
\end{tabular}

${ }^{a}$ Measured at $0.2 \mathrm{~V} \mathrm{~s}^{-1} \cdot{ }^{b}$ Peak potential value for processes accompanied by chemical complications. ${ }^{c}$ Two-electron process coupled to chemical complications. ${ }^{d}$ From OSWV.

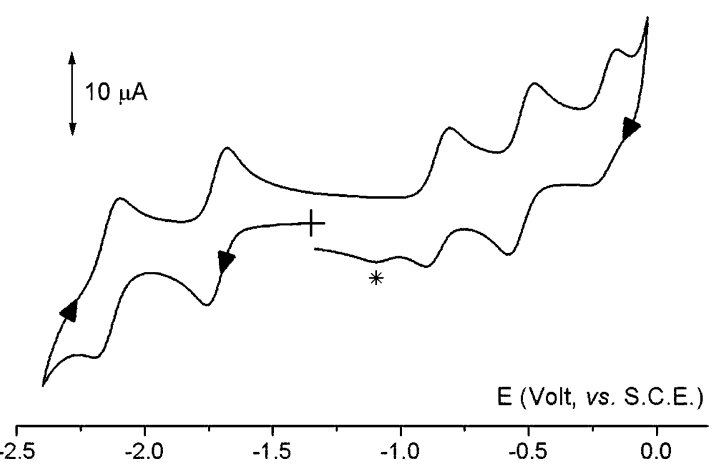

Figure 1. Cyclic voltammogram recorded at a platinum electrode on a MeCN solution of $\left[\mathrm{NMe}_{4}\right]_{4}\left[\mathrm{Co}_{10} \mathrm{~N}_{2}(\mathrm{CO})_{19}\right]\left(1.3 \times 10^{-3} \mathrm{~mol} \mathrm{dm}^{-3}\right)\left(\left[\mathrm{NBu}_{4}\right]-\right.$ $\left[\mathrm{PF}_{6}\right]\left(0.1 \mathrm{~mol} \mathrm{dm}^{-3}\right)$ supporting electrolyte; scan rate $\left.0.2 \mathrm{~V} \mathrm{~s}^{-1}\right)$.

significant amounts of the octahedral cluster $\left[\mathrm{Co}_{6} \mathrm{~N}(\mathrm{CO})_{13}\right]^{-}$ (2) ${ }^{16}$ and even traces of its $\mathrm{CO}$-addition product $\left[\mathrm{Co}_{6} \mathrm{~N}(\mathrm{CO})_{15}\right]^{-}$ (1). ${ }^{12}$ Very likely, here $\mathrm{CO}$ triggers more than one reaction running in sequence and/or parallel paths, involving several fragmentation and recondensation equilibria. Excess $\mathrm{CO}$ (up to a total of $10 \mathrm{~mol}$ of $\mathrm{CO} / \mathrm{mol}$ of $\mathbf{3}$ ) decomposes completely also $\mathbf{C}$, leaving only $\left[\mathrm{Co}_{6} \mathrm{~N}(\mathrm{CO})_{15}\right]^{-}$and $\left[\mathrm{Co}(\mathrm{CO})_{4}\right]^{-}$as the ultimate products of the degradation, hence indefinitely stable under $1 \mathrm{~atm}$ of $\mathrm{CO}$. Also anion $\mathbf{C}$, fairly stable in solution under nitrogen, becomes elusive when its isolation from the reaction mixture is attempted. Thus, metathesis of the cesium salt with bulky organic cations, or just the addition of a precipitating solvent, invariably yields the 11-metal cluster anion 4 . In fact, the best way to obtain $\mathbf{4}$ is a cycle of a few precipitations (by addition of $n$-hexane or toluene) followed by redissolution (in acetone or $\mathrm{MeCN}$ ); IR spectra show that, eventually, the product is obtained almost pure. It must be remarked that the $\left[\mathrm{Co}_{11} \mathrm{~N}_{2}(\mathrm{CO})_{21}\right]^{3-}$ anion was never detected in the above-mentioned sequence induced by $\mathrm{CO}$. The elusive anion $\mathbf{C}$ is pivotal within this chemistry. It can be regenerated from anion 4 by reaction with acids, another proof of the connection between the two species. Moreover, evidence of anion $\mathbf{C}$ was also obtained when the $\left[\mathrm{Co}_{6} \mathrm{~N}(\mathrm{CO})_{15}\right]^{-}$anion was reacted with $\mathrm{Me}_{3} \mathrm{NO}$ (Scheme 1); 2 mol of the decarbonylating agent gives at first the octahedral cluster $\mathbf{2}$ and an excess yields anion $\mathbf{C}$. Formally, this reaction may be considered the reversal of the $\mathrm{CO}$ addition that, from $\mathbf{C}$, eventually leads to $\left[\mathrm{Co}_{6} \mathrm{~N}(\mathrm{CO})_{15}\right]^{-}$.

2. Electrochemistry and Coupled EPR Measurements. Figure 1 shows the cyclic voltammetric behavior of the tetraanion $\left[\mathrm{Co}_{10} \mathrm{~N}_{2}(\mathrm{CO})_{19}\right]^{4-}$ in $\mathrm{MeCN}$ solution. It undergoes either three successive oxidations or two successive reductions, which, but for the most anodic step, exhibit features of chemical reversibility in the cyclic voltammetric time

(16) Ciani, G.; Martinengo, S. J. Organomet. Chem. 1986, 306, C49.

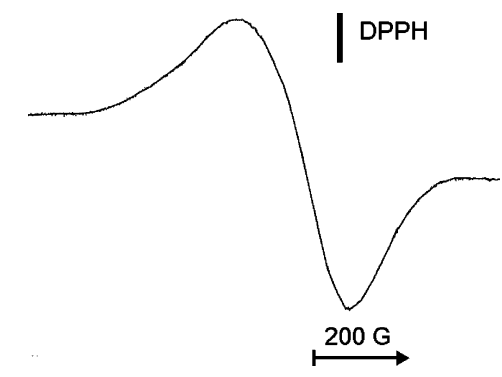

Figure 2. $\mathrm{X}$-band $\mathrm{EPR}$ spectrum of a $\mathrm{MeCN}$ solution of the trianion $\left[\mathrm{Co}_{10} \mathrm{~N}_{2}(\mathrm{CO})_{19}\right]^{3-}$ at $T=105 \mathrm{~K}$.

scale. The spurious starred peak in the backscan arises from the chemical complications accompanying the most anodic process. In fact, step-by-step controlled-potential coulometry showed that each of the first two oxidations involve one electron/molecule. In confirmation of the complete chemical reversibility of such processes, cyclic voltammetric tests carried out on the solutions resulting from each exhaustive one-electron removal afforded profiles quite complementary to the original ones. Given the similar peak heights of the reduction processes, it follows that the present cluster can shuttle reversibly the rich sequence $\left[\mathrm{Co}_{10} \mathrm{~N}_{2}(\mathrm{CO})_{19}\right]^{2-13-/ 4-15-16-}$. Analysis ${ }^{17}$ of the cyclic voltammograms with scan rate varying from 0.02 to $2.0 \mathrm{~V} \mathrm{~s}^{-1}$ agrees not only with the chemical reversibility of the different redox changes $\left(i_{\text {p(reverse })} /\right.$ $i_{\text {p(direct) }}$ constantly equal to 1 for each process) but also with their electrochemical reversibility $\left(\Delta E_{\mathrm{p}}\right.$ close to the theoretical value of $59 \mathrm{mV}$ ), which foreshadows that no significant structural changes accompany the pertinent electron removals. The formal electrode potentials for the cited electrontransfer processes are compiled in Table 2 (together with those of $\left[\mathrm{Co}_{11} \mathrm{~N}_{2}(\mathrm{CO})_{21}\right]^{3-}$ which will be discussed below).

In view of the chemical stability of the species $\left[\mathrm{Co}_{10} \mathrm{~N}_{2^{-}}\right.$ $\left.(\mathrm{CO})_{19}\right]^{3-}$ and $\left[\mathrm{Co}_{10} \mathrm{~N}_{2}(\mathrm{CO})_{19}\right]^{2-}$, EPR measurements have been carried out on the solutions resulting from the pertinent exhaustive oxidations. Figure 2 shows the frozen solution $\mathrm{X}$-band EPR spectrum of the trianion $\left[\mathrm{Co}_{10} \mathrm{~N}_{2}(\mathrm{CO})_{19}\right]^{3-}$. The line shape analysis is suitably performed by taking into account the $S=1 / 2$ doublet state electron spin Hamiltonian in an anisotropic axial structure $\left(g_{\|}>g_{\perp} \neq g_{\text {electron }}=2.0023\right)$. The broad and intense signal displays two poorly resolved absorptions (first and second derivative mode) partially overlapped in the intermediate field. The paramagnetic features are the following: $g_{\|}=2.274(5) ; g_{\perp}=2.034(5)$; $\langle g\rangle=\left(g_{\|}+2 g_{\perp}\right) / 3=2.114(5)$. The $g_{\mathrm{i}}$ values are diagnostic of a metal-centered radical as a consequence of the strong cobalt spin-orbit coupling (SO coupling constant $l<0$ ) even

(17) Brown, E. R.; Sandifer, J. R. In Physical Methods of Chemistry, Electrochemical Methods; Rossiter, B. W., Hamilton, J. F., Eds.; Wiley: New York, 1986; Vol. 2, Chapter 4. 

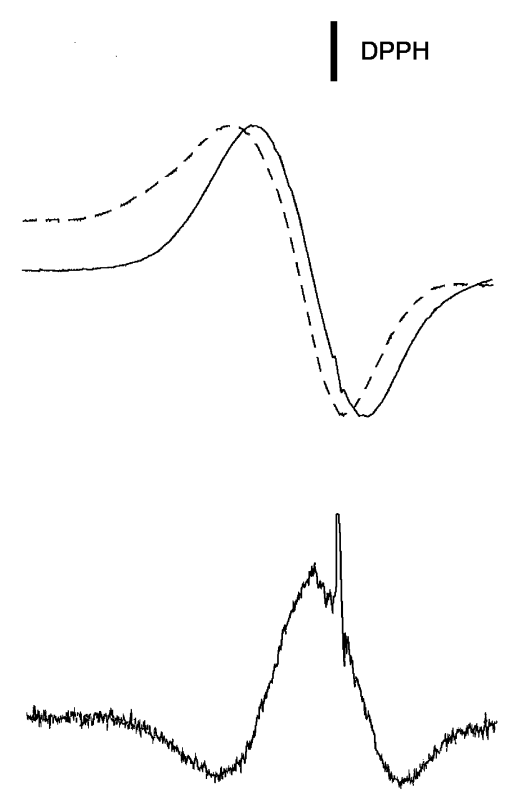

$200 \mathrm{G}$

Figure 3. X-band EPR spectra of a $\mathrm{MeCN}$ solution of the dianion $\left[\mathrm{Co}_{10} \mathrm{~N}_{2-}\right.$ $\left.(\mathrm{CO})_{19}\right]^{2-}:$ top, first derivative; bottom, second derivative. $T=105 \mathrm{~K}$. (--) $\mathrm{X}$-band spectrum of the trianion $\left[\mathrm{Co}_{10} \mathrm{~N}_{2}(\mathrm{CO})_{19}\right]^{3-}$ under the same experimental conditions.

if neither ${ }^{59} \mathrm{Co}\left({ }^{59} \mathrm{Co}: I=7 / 2\right.$, natural abundance $\left.=100 \%\right)$ nor ${ }^{14} \mathrm{~N}\left({ }^{14} \mathrm{~N}: I=1\right.$, natural abundance $\left.=99.6 \%\right)$ hyperfine (hpf) splittings are detected. The perpendicular peak-to-peak line width, $\Delta H_{\perp}=218(5) \mathrm{G}$, allows us to state an upper limit for the magnetic interactions (if any): $\Delta H_{\perp} \geq a_{\perp}(\mathrm{Co}$, $\mathrm{N})$. This behavior is not surprising in view of the high nuclearity of the paramagnetic species and suggests the fundamental delocalization of the unpaired electron over the whole cobalt frame. ${ }^{18,19}$ With increase of the temperature at the glassy-fluid transition ( $T=226 \mathrm{~K})$, the anisotropic spectrum quickly drops out and the fluid solution becomes EPR silent, but refreezing the fluid solution quantitatively restores the original anisotropic features, indicating basic stability of the trianion. ${ }^{19,20}$

Figure 3 in turn shows the low-temperature X-band EPR spectrum of the dianion $\left[\mathrm{Co}_{10} \mathrm{~N}_{2}(\mathrm{CO})_{19}\right]^{2-}$ (first and second derivative mode), also in comparison with that of the trianion $\left[\mathrm{Co}_{10} \mathrm{~N}_{2}(\mathrm{CO})_{19}\right]^{3-}$. The spectrum exhibits a line shape consistent with one intense and broad pseudoisotropic signal (as confirmed by the second derivative mode), totally unresolved and centered at $g_{\text {pseudoiso }}(105 \mathrm{~K})=2.017(8)$. The corresponding $\Delta H_{\text {pseudoiso }}(105 \mathrm{~K})$ is $225(8) \mathrm{G}$. The line shape

(18) (a) Barbaro, P.; Cecconi, F.; Ghilardi, C. A.; Midollini, S.; Orlandini, A.; Fabrizi de Biani, F.; Laschi, F.; Zanello, P. J. Chem. Soc., Dalton Trans. 1996, 4337. (b) Bachert, I.; Braunstein, P.; Fabrizi de Biani, F.; Laschi, F.; Zanello, P.; Kickelbick, G.; Schubert, U. J. Organomet. Chem. 1999, 573, 47. (c) Schneider, J. J.; Spickermann, D.; Labahn, T.; Magull, J.; Fontani, M.; Laschi, F.; Zanello, P. Chem.-Eur. J. 2000, 6, 3686. (d) Ciani, G.; Sironi, A.; Martinengo, S.; Garlaschelli, L.; DellaPergola, R.; Zanello, P.; Laschi, F.; Masciocchi, N. Inorg. Chem. 2001, 40, 3905.

(19) Mabbs, F. E.; Collison, D. In Electron Paramagnetic Resonance of d Transition Metal Compounds; Studies in Inorganic Chemistry; Elsevier: New York, 1992; Vol. 16.

(20) Drago, R. S. In Physical Methods for Chemists; Saunders College Publ.: New York, 1992.

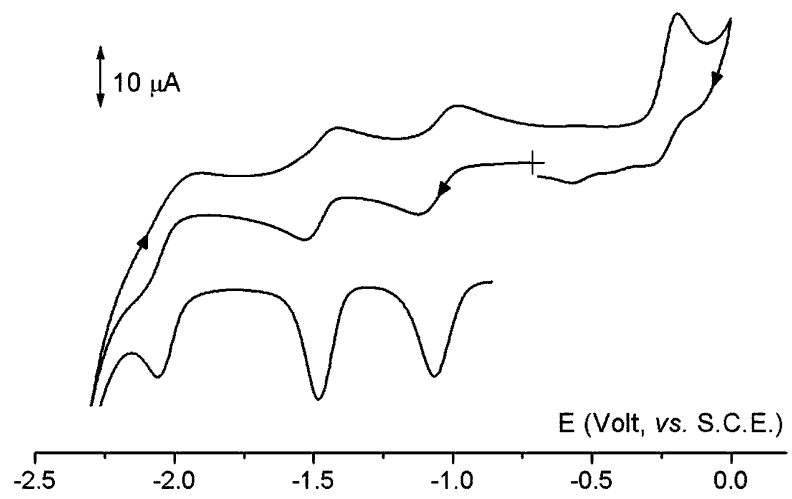

Figure 4. Cyclic (top) and Osteryoung square wave (bottom) voltammograms recorded at a platinum electrode in a $\mathrm{MeCN}$ solution of $\left[\mathrm{NMe}_{4}\right]_{3-}$ $\left[\mathrm{Co}_{11} \mathrm{~N}_{2}(\mathrm{CO})_{21}\right]\left(1.5 \times 10^{-3} \mathrm{~mol} \mathrm{dm}^{-3}\right)\left(\left[\mathrm{NBu}_{4}\right]\left[\mathrm{PF}_{6}\right]\left(0.1 \mathrm{~mol} \mathrm{dm}^{-3}\right)\right.$ supporting electrolyte; scan rates (top) $0.2 \mathrm{~V} \mathrm{~s}^{-1}$ and (bottom) $0.1 \mathrm{~V} \mathrm{~s}^{-1}$ ).

can be suitably interpreted by assuming an $S=1$ (triplet state) electron spin Hamiltonian with two main terms: (i) the Zeeman interaction Hamiltonian; (ii) the zero-field splitting (ZFS) ${ }^{19,20}$ In the field scan of $50-6500 \mathrm{G}$, only one signal is detectable at the actual frequency $v=9.44$ GHz. The unstructured signal is attributable to the first-order (permitted) ZFS transitions between the two $M_{S}= \pm 1 \leftrightarrow 0$ electron spin states, the actual $v$ being larger than the $S=1$ ZFS energy interaction. As shown, the actual $g_{\text {pseudoiso }}$ is significantly lower than that of the corresponding trianion and well accounts for the presence of two magnetically coupled unpaired electrons, even if with a reduced $3 \mathrm{~d}$ Co orbital contribution with respect to the trianion. Also in this case, neither Co nor $\mathrm{N}$ hpf magnetic interactions are detected $\left(\Delta H_{\text {pseudoiso }} \geq a_{\perp}(\mathrm{Co}, \mathrm{N})\right)$. With increase of the temperature at the glassy-fluid transition, the signal disappears. Refreezing the solution only partially restores the original signal, thus suggesting that under a not inert atmosphere the dianion is more fragile than the trianion.

Let us now move to the $\left[\mathrm{Co}_{11} \mathrm{~N}_{2}(\mathrm{CO})_{21}\right]^{3-}$ trianion. Figure 4 shows its voltammetric behavior in $\mathrm{MeCN}$ solution. It exhibits three subsequent reductions and one oxidation process. Controlled-potential coulometry proved the oneelectron nature of the first cathodic step (see below), so that the overall redox activity can be in principle depicted as

$$
\begin{aligned}
& {\left[\mathrm{Co}_{11} \mathrm{~N}_{2}(\mathrm{CO})_{21}\right]^{-\stackrel{-2 \mathrm{e}}{\leftrightarrows}}\left[\mathrm{Co}_{11} \mathrm{~N}_{2}(\mathrm{CO})_{21}\right]^{3-} \stackrel{+\mathrm{e}}{\leftrightarrows}} \\
& {\left[\mathrm{Co}_{11} \mathrm{~N}_{2}(\mathrm{CO})_{21}\right]^{4-} \stackrel{+\mathrm{e}}{\rightleftarrows}\left[\mathrm{Co}_{11} \mathrm{~N}_{2}(\mathrm{CO})_{21}\right]^{5-} \stackrel{+\mathrm{e}}{\rightleftarrows}} \\
& {\left[\mathrm{Co}_{11} \mathrm{~N}_{2}(\mathrm{CO})_{21}\right]^{6-}}
\end{aligned}
$$

The pertinent formal electrode potentials are summarized in Table 2. Despite the features of chemical reversibility of the two first reduction processes in the cyclic voltammetric time scale, in reality room-temperature controlled-potential coulometry in correspondence of the first cathodic step $\left(E_{\mathrm{w}}=\right.$ $-1.2 \mathrm{~V})$ revealed partial decomposition of the electrogenerated tetraanion $\left[\mathrm{Co}_{11} \mathrm{~N}_{2}(\mathrm{CO})_{21}\right]^{4-}$. It is also noted that the large departure of the peak-to-peak separation from 59 $\mathrm{mV}$ suggests that a rather high reorganization energy accompanies the electron additions. Controlled-potential electrolysis at low temperature $\left(-20{ }^{\circ} \mathrm{C}\right)$ allowed EPR 


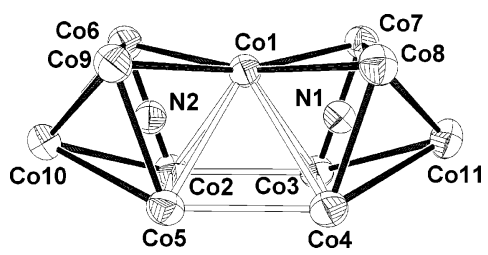

Figure 5. View of the metal cage of the $\left[\mathrm{Co}_{11} \mathrm{~N}_{2}(\mathrm{CO})_{21}\right]^{3-}$ trianion, highlighting the labeling and the "internal" square pyramid formed by merging two octahedra.

characterization of the tetraanion $\left[\mathrm{Co}_{11} \mathrm{~N}_{2}(\mathrm{CO})_{21}\right]^{4-}$. Under glassy conditions $(T=105 \mathrm{~K})$, it exhibits a broad spectrum $\left(\Delta H_{\text {averaged }}=270(8) \mathrm{G}\right)$, the $g_{\text {averaged }}$ value $(2.054(8))$ of which is significantly higher than that of the $g_{\text {electron. Such features, }}$ also in this case, indicate a significant metallic character. Also in this case, no spectral resolutions of the $g_{\text {averaged }}$ as well as of the $a_{\mathrm{i}}$ hpf Co magnetic features are evident $\left(\Delta H_{\text {averaged }} \geq a_{\text {averaged }}(\mathrm{Co}, \mathrm{N})\right)$. With increase of the temperature at the glassy-fluid transition, the signal drops out, and in agreement with the electrochemical findings, fast refreezing of the solution only partially regenerates the original signal.

3. Crystal Structure of $\left[\mathrm{Co}_{11} \mathrm{~N}_{2}(\mathrm{CO})_{21}\right]\left[\mathrm{NMe}_{4}\right]_{3} \cdot \mathrm{Me}_{2} \mathrm{CO}$ and $\left[\mathrm{Co}_{11} \mathbf{N}_{2}(\mathrm{CO})_{21}\right]\left[\mathrm{NBu}_{4}\right]_{2} \mathrm{Cs}$. The $\left[\mathrm{Co}_{11} \mathrm{~N}_{2}(\mathrm{CO})_{21}\right]^{3-}$ anion (4) has been structurally characterized both as tetramethylammonium salt (acetone solvate) and as a mixed cesium/ tetrabutylammonium salt (4a,b, respectively). The trianion is apparently isoelectronic and related to the corresponding carbide $\left[\mathrm{Co}_{11} \mathrm{C}_{2}(\mathrm{CO})_{22}\right]^{3-} \cdot{ }^{14}$ However, while the latter has a tricapped cubic metal cage, of $C_{s}$ symmetry, with a large internal cavity containing a $\mathrm{C}_{2}$ unit $(\mathrm{C}-\mathrm{C} 1.62(5) \AA)$, the former possesses a "bent" bioctahedral metal cage, of idealized $C_{2 v}$ symmetry, containing two nitrides (one for each octahedral cavity) $3.28 \AA$ apart. This "bent" bioctahedral metal cage is formally assembled by two sequential condensations of octahedra on two opposite triangular faces of a square pyramid (see Figure 5). This formal operation allows also to apply Mingos' condensed polyhedron rule,$^{21}$ to derive the expected cluster valence electron (CVE) number for the given shape of the metal cage. Thus, for an octahedron condensed with a square pyramid trough a triangular face we expect $(86+74-48) 112 \mathrm{CVE}$ while upon a second condensation (of an octahedron trough a triangular face) we expect $(112+86-48) 150$ CVE. Actually, the $\left[\mathrm{Co}_{11} \mathrm{~N}_{2^{-}}\right.$ $\left.(\mathrm{CO})_{21}\right]^{3-}$ anion possesses four more CVEs (i.e. 154) and we have to look at its stereochemistry in more detail to ascertain the origin of this discrepancy.

The distribution of the 21 carbonyl ligands about the metal cage, 11 terminal (one for each metal atom) and 10 double bridging (as highlighted in Figure 6 by the solid bonds), strongly resembles that of the only other cobalt cluster having a nitride into an octahedral cavity, namely $\left[\mathrm{Co}_{6} \mathrm{~N}(\mathrm{CO})_{13}\right]^{-.22}$ Indeed, both the cage and the ligand stereochemistry of $\left[\mathrm{Co}_{11} \mathrm{~N}_{2}(\mathrm{CO})_{21}\right]^{3-}$ result from the condensation of two $\left[\mathrm{Co}_{6} \mathrm{~N}(\mathrm{CO})_{13}\right]^{-}$anions (by merging a couple of atoms and creating two new bonds; see Figure 6 and 7).

(21) Mingos, D. M. P. J. Chem. Soc., Chem. Commun. 1983, 706.

(22) Ciani, G.; Martinengo, S. J. Organomet. Chem. 1986, 306, C49.

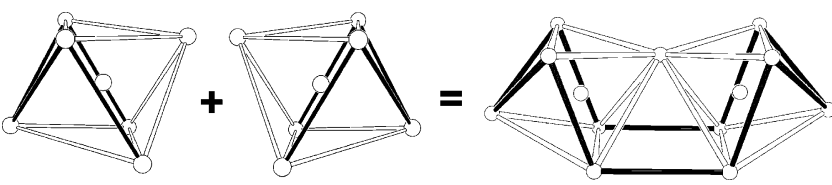

Figure 6. Formal condensation of two $\left[\mathrm{Co}_{6} \mathrm{~N}(\mathrm{CO})_{13}\right]^{-}$to afford the $\left[\mathrm{Co}_{11} \mathrm{~N}_{2}(\mathrm{CO})_{21}\right]^{3-}$. Note that the location of bridging carbonyls (solid bonds) is preserved upon condensation.
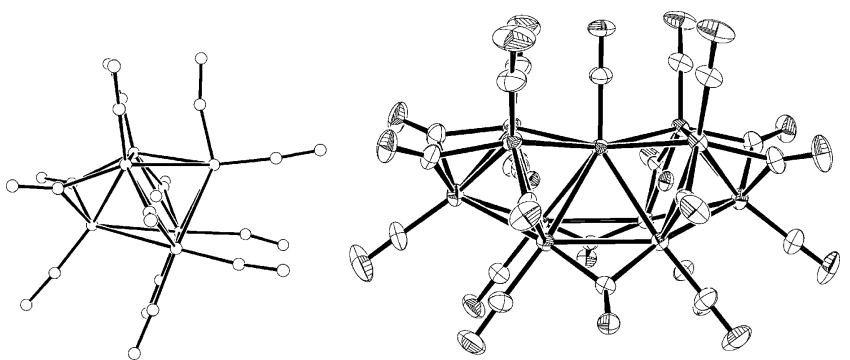

Figure 7. View of the $\left[\mathrm{Co}_{6} \mathrm{~N}(\mathrm{CO})_{13}\right]^{-}$and $\left[\mathrm{Co}_{11} \mathrm{~N}_{2}(\mathrm{CO})_{21}\right]^{3-}$ clusters highlighting the close relationship between their ligand stereochemistries.

Table 3. Analysis of the $\mathrm{Co}-\mathrm{Co}$ Bond Distances in $\left[\mathrm{Co}_{11} \mathrm{~N}_{2}(\mathrm{CO})_{21}\right]^{3-}$ $(\mathbf{4 a}, \mathbf{b})$ and $\left[\mathrm{Co}_{6} \mathrm{~N}(\mathrm{CO})_{13}\right]^{-}(\mathbf{2})^{a}$

\begin{tabular}{lccc}
\hline & $\mathbf{4 a},\left[\mathrm{NMe}_{4}\right]_{3}$ salt & $\mathbf{4 b},\left[\mathrm{NBu}_{4}\right]_{2} \mathrm{Cs}$ salt & {$\left[\mathrm{Co}_{6} \mathrm{~N}(\mathrm{CO})_{13}\right]^{-}$} \\
\hline $\operatorname{Co}(1)-\operatorname{Co}(2)$ & $2.835(1)$ & $2.809(1)$ & $>2.604$ \\
$\operatorname{Co}(1)-\operatorname{Co}(3)$ & $2.817(1)$ & $2.822(1)$ & $>2.604$ \\
$\operatorname{Co}(1)-\operatorname{Co}(4)$ & $2.856(1)$ & $2.846(2)$ & $>2.604$ \\
$\operatorname{Co}(1)-\operatorname{Co}(5)$ & $2.810(1)$ & $2.811(1)$ & $>2.604$ \\
$\operatorname{Co}(1)-\operatorname{Co}(6)$ & $2.608(1)$ & $2.596(1)$ & $<2.627$ \\
$\operatorname{Co}(1)-\operatorname{Co}(7)$ & $2.577(1)$ & $2.599(1)$ & $<2.627$ \\
$\operatorname{Co}(1)-\operatorname{Co}(8)$ & $2.596(1)$ & $2.583(1)$ & $<2.627$ \\
$\operatorname{Co}(1)-\operatorname{Co}(9)$ & $2.578(1)$ & $2.596(1)$ & $<2.627$ \\
$\operatorname{Co}(2)-\operatorname{Co}(10)$ & $2.681(1)$ & $2.691(1)$ & $\approx 2.692$ \\
$\operatorname{Co}(2)-\operatorname{Co}(5)$ & $\mathbf{2 . 7 3 8 ( 1 )}$ & $\mathbf{2 . 8 0 0 ( 2 )}$ & 2.720 \\
$\operatorname{Co}(2)-\operatorname{Co}(6)$ & $2.522(1)$ & $2.523(1)$ & $\approx 2.514$ \\
$\operatorname{Co}(3)-\operatorname{Co}(11)$ & $2.703(1)$ & $2.701(1)$ & $\approx 2.692$ \\
$\operatorname{Co}(3)-\operatorname{Co}(2)$ & $2.689(1)$ & $2.694(1)$ & \\
$\operatorname{Co}(3)-\operatorname{Co}(4)$ & $\mathbf{2 . 7 1 9 ( 1 )}$ & $\mathbf{2 . 7 5 4 ( 2 )}$ & $\approx 2.720$ \\
$\operatorname{Co}(3)-\operatorname{Co}(7)$ & $2.527(1)$ & $2.511(1)$ & $\approx 2.514$ \\
$\operatorname{Co}(4)-\operatorname{Co}(11)$ & $2.679(1)$ & $2.677(1)$ & $<2.692$ \\
$\operatorname{Co}(4)-\operatorname{Co}(8)$ & $2.517(1)$ & $2.504(1)$ & $\approx 2.514$ \\
$\operatorname{Co}(5)-\operatorname{Co}(10)$ & $2.668(1)$ & $2.669(1)$ & $<2.692$ \\
$\operatorname{Co}(5)-\operatorname{Co}(4)$ & $2.689(1)$ & $2.679(1)$ & \\
$\operatorname{Co}(5)-\operatorname{Co}(9)$ & $2.533(1)$ & $2.517(1)$ & $\approx 2.514$ \\
$\operatorname{Co}(6)-\operatorname{Co}(10)$ & $2.481(1)$ & $2.480(1)$ & $\approx 2.489$ \\
$\operatorname{Co}(6)-\operatorname{Co}(9)$ & $\mathbf{2 . 8 2 3}(\mathbf{1})$ & $\mathbf{2 . 7 6 7 ( 2 )}$ & 2.788 \\
$\operatorname{Co}(7)-\operatorname{Co}(11)$ & $2.471(1)$ & $2.469(2)$ & $\approx 2.489$ \\
$\operatorname{Co}(7)-\operatorname{Co}(8)$ & $2.852(1)$ & $2.861(2)$ & $>2.788$ \\
$\operatorname{Co}(8)-\operatorname{Co}(11)$ & $2.479(1)$ & $2.483(1)$ & $\approx 2.489$ \\
$\operatorname{Co}(9)-\operatorname{Co}(10)$ & $2.481(1)$ & $2.479(1)$ & $\approx 2.489$ \\
& & &
\end{tabular}

${ }^{a}$ The distances of the latter anion are from ref 22 and symmetry $\left(C_{s}\right)$ averaged. Bold characters highlight the major differences between $\mathbf{4 a}$ and $4 b$.

A close analysis of the $\mathrm{Co}-\mathrm{Co}$ bond distances reported in Table 3 clearly shows that most of the edges of the "internal" square pyramid are elongated. This is particularly true for the four basal-to-vertex edges which, upon cluster condensation, lengthen from $2.604 \AA$ (in the "parent" $\left[\mathrm{Co}_{6} \mathrm{~N}(\mathrm{CO})_{13}\right]^{-}$anion) to $2.826 \AA$ (averaged over $\mathbf{4 a}, \mathbf{b}$ ) and for the two newborn bonds, $\mathrm{Co} 2-\mathrm{Co} 3$ and $\mathrm{Co} 4-\mathrm{Co} 5$, which are much longer than the other, carbonyl-bridged, $\mathrm{Co}-\mathrm{Co}$ interactions present in the $\left[\mathrm{Co}_{11} \mathrm{~N}_{2}(\mathrm{CO})_{21}\right]^{3-}$ anion (2.688 vs $2.478 \AA$ ). Accordingly, the four CVE in excess do not promote the breaking of two "definite" bonds (hence a substantial change in the metal cage skeleton) but belong to two antibonding orbitals (reasonably, the HOMO and the 
Fumagalli et al.

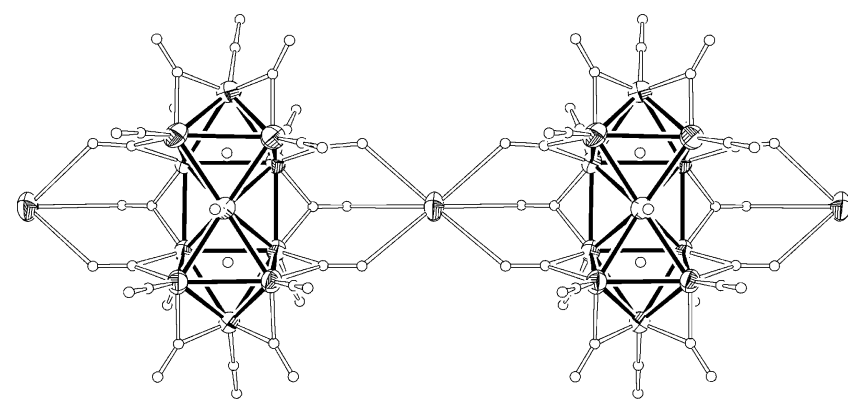

Figure 8. View of the "chains", running along the [100] direction, promoted by the presence of the "acidic" cesium cations in the $\left[\mathrm{Co}_{11} \mathrm{~N}_{2-}\right.$ $\left.(\mathrm{CO})_{21}\right]\left[\mathrm{NBu}_{4}\right]_{2} \mathrm{Cs}$ salt.

NHOMO of the cluster) whose antibonding character is delocalized over "all" square pyramid edges. According to this picture these electrons in excess should be easily removed, provided that the shortening of the formerly elongated bonds does not promote severe ligand crowding. Indeed, as observed by cyclic voltametry, see above, only two electrons can be easily and reversibly removed.

On variation of the countercations, there are significant changes in the supramolecular organization. While the tetramethylammonium salt is constituted of "non locally interacting" ions (and acetone molecules), in the mixed cesium/tetrabutylammonium salt, the presence of the "acidic" cesium cations promotes the formation of chains (see Figure 8 ), running along the [100] direction. The coordination geometry of the cesium cation, which is "connected" to six bridging carbonyl oxygens (Cs $\cdots \mathrm{O}$ in the range $3.04-3.07$ $\AA$ ), is trigonal prismatic. Changes in the molecular packing slightly perturb the overall stereochemistry of the anion. At the metal cage level, the effect of the different counteranion may be monitored in Table 3, where clearly a few metalmetal bond distances (Co2-Co5, $\mathrm{Co} 6-\mathrm{Co} 9$, and, to a lesser extent, $\mathrm{Co} 3-\mathrm{Co} 4)$ are different in the two salts. Noteworthy, the interested metals are those supporting the bridging carbonyls whose oxygen atoms "coordinate" the cesium cation. As a matter of fact, if we look for the best superimposition of the two anion by translating and rotating $\mathbf{4 a}$ within the lattice of $\mathbf{4 b}$ (as it is possible with IDEAL, ${ }^{23}$ the root-mean-displacement between the two anions is 0.15 $\AA$ ), we observe that while the coordination of the Cs atom with $\mathbf{4 b}$ is "regular" (Cs $\cdots \mathrm{O}$ in the range $3.04-3.07 \AA)$ it becomes more loose and asymmetric ( $\mathrm{Cs} \cdots \mathrm{O}$ in the range 3.05-3.30 ̊) when $\mathbf{4 b}$ is "substituted" by $\mathbf{4 a}$. Thus, we suggest that it is the cesium atom which mainly promotes the (small) stereochemical differences between $\mathbf{4 a}$ and $\mathbf{4 b}$. Obviously, carbonyl motions about the metal cage are correlated; thus, we observe also significant "movements" of the terminal carbonyl ligands connected to the above quoted metal atoms.

\section{Conclusions}

The chemical behavior of the $\left[\mathrm{Co}_{10} \mathrm{~N}_{2}(\mathrm{CO})_{19}\right]^{4-}$ anion exemplifies two different kinds of reaction typical of high-

(23) Gould, R. O.; Moulden, N.; Taylor, P. IDEAL; Department of Chemistry, University of Edinburgh: Edinburgh, U.K., 1988. nuclearity clusters: the reversible electron transfer propensity (which generally causes minor deformations of the metal cage) and more important cluster reassembling which may even prelude changes in nuclearity (by condensation or cleavage of metal fragments). Thus, studies of redox reactivity by electrochemical and chemical means are complementary, in light of their different time scales: the first ones are best used to track fast outer-sphere electron transfer, and the second, to detect deeper structural reorganizations, which affect the geometry of the metal cages.

The tendency of the interstitial atom to preserve its metallic environment withstanding cluster fragmentation is particularly evident here: first of all, $\mathrm{Co}-\mathrm{N}$ bonds minimize formation of $\left[\mathrm{Co}(\mathrm{CO})_{4}\right]^{-}$(this carbonyl anion is ubiquitous in the chemistry of carbonyl cobalt clusters, owing to strong $\mathrm{Co}-\mathrm{CO}$ and relatively weak $\mathrm{Co}-\mathrm{Co}$ interactions). More interesting, as also observed for the recently reported $\left[\mathrm{Co}_{13} \mathrm{~N}_{2}(\mathrm{CO})_{24}\right]^{3-,},{ }^{6}$ it appears that polynitrido species are built up by fairly rigid units, containing interstitial atoms, linked by more loose $\mathrm{Co}-\mathrm{Co}$ bonds, and that these intercage empty polyhedra can act as a sink for additional valence electrons.

\section{Experimental Section}

All operations were carried out under nitrogen or carbon monoxide where specified, with a standard Schlenk tube apparatus. Tetrahydrofuran was distilled from sodium-benzophenone. All other analytical grade solvents were degassed in a vacuum and stored under nitrogen with $3 \AA$ molecular sieves. $\mathrm{Cs}_{4}\left[\mathrm{Co}_{10} \mathrm{~N}_{2}(\mathrm{CO})_{19}\right]$ was prepared by the published method. ${ }^{5}$ Infrared spectra were recorded on Nicolet Avatar 360 FT-IR spectrophotometer, using $0.1-\mathrm{mm} \mathrm{CaF}_{2}$ cells previously purged with nitrogen. Materials and apparatus for electrochemistry and coupled EPR measurements have been described elsewhere. ${ }^{18 \mathrm{~d}}$ All the potential values are referred to the saturated calomel electrode (SCE). Under the present experimental conditions, the one electron oxidation of ferrocene occurs at $+0.38 \mathrm{~V}$.

1. Synthesis of $\left[\mathrm{Co}_{11} \mathrm{~N}_{2}(\mathrm{CO})_{21}\right]^{3-}$ Anion. (a) As $\left[\mathrm{NMe}_{4}\right]^{+}$Salt, via the Anion C. $\mathrm{Cs}_{4}\left[\mathrm{Co}_{10} \mathrm{~N}_{2}(\mathrm{CO})_{19}\right](765 \mathrm{mg}, 0.455 \mathrm{mmol})$ in acetone $(30 \mathrm{~mL})$, while stirring, was treated at room temperature with ca. $92 \mathrm{~mL}$ of $\mathrm{CO}$ in several portions; at the appearance of the IR bands of anion $\mathbf{C}$ at $2001 \mathrm{~s}, 1978 \mathrm{~s}$, and $1836 \mathrm{~cm}^{-1}$ together with that of $\left[\mathrm{Co}(\mathrm{CO})_{4}\right]^{-}\left(1890 \mathrm{~cm}^{-1}\right)$ the solution was treated with hexane $(50 \mathrm{~mL})$. This caused precipitation of a tacky product and a residual red-brown mother liquor that was discarded. The precipitate was redissolved in acetone and again reprecipitated, discarding the mother liquor; this cycle was repeated until IR in acetone did show only bands of the product at 1973 and $1822 \mathrm{~cm}^{-1}$. This solution was treated while stirring with $\left[\mathrm{NMe}_{4}\right] \mathrm{Cl}(1.2 \mathrm{~g})$ in $\mathrm{MeOH}(10 \mathrm{~mL})$ and 2-propanol $(30 \mathrm{~mL})$ to induce precipitation and subsequently $20 \mathrm{~mL}$ more of 2-propanol. After $10 \mathrm{~min}$, the precipitate was recovered by filtration, washed with 2-propanol (3 $\times 2 \mathrm{~mL}$ ), and vacuum-dried. Recrystallization was done by dissolution with acetone $(9 \mathrm{~mL})$ and careful layering 2-propanol $(30 \mathrm{~mL})$. When the diffusion was completed, black crystals of $\left[\mathrm{NMe}_{4}\right]_{3}\left[\mathrm{Co}_{11} \mathrm{~N}_{2}(\mathrm{CO})_{21}\right] \cdot$ acetone were recovered, thoroughly washed with 2-propanol, and vacuum-dried. Yield: $116 \mathrm{mg}$. Anal. Found (calcd) for $\mathrm{C}_{36} \mathrm{H}_{42} \mathrm{Co}_{11} \mathrm{~N}_{5} \mathrm{O}_{22}$ : C, 27.93 (27.99); $\mathrm{H}, 3.36$ (2.74); $\mathrm{N}$, $4.42(4.53)$.

This synthesis may be performed by starting directly from the $\left(\mathrm{NMe}_{4}\right)_{4}\left[\mathrm{Co}_{10} \mathrm{~N}_{2}(\mathrm{CO})_{19}\right]$ salt. In this case, the reaction with $\mathrm{CO}$ to obtain anion $\mathbf{C}$ as above reported is best performed in $\mathrm{MeCN}$. After 
Table 4. Crystal and Structure Refinement Data for $\left[\mathrm{NMe}_{4}\right]_{3}\left[\mathrm{Co}_{11} \mathrm{~N}_{2}(\mathrm{CO})_{21}\right] \cdot \mathrm{Me}_{2} \mathrm{CO}(\mathbf{4 a})$ and $\left[\mathrm{NBu}_{4}\right]_{2} \mathrm{Cs}\left[\mathrm{Co}_{11} \mathrm{~N}_{2}(\mathrm{CO})_{21}\right](\mathbf{4 b})^{a}$

\begin{tabular}{|c|c|c|}
\hline & $4 \mathrm{a}$ & $4 \mathrm{~b}$ \\
\hline empirical formula & $\mathrm{C}_{36} \mathrm{H}_{42} \mathrm{Co}_{11} \mathrm{~N}_{5} \mathrm{O}_{22}$ & $\mathrm{C}_{53} \mathrm{H}_{72} \mathrm{Co}_{11} \mathrm{CsN}_{4} \mathrm{O}_{21}$ \\
\hline & 1544.98 & 1882.29 \\
\hline temp, $\mathrm{K}$ & 293(2) & $293(2)$ \\
\hline wavelength, $\AA$ & 0.71073 & 0.71073 \\
\hline cryst system, space group & monoclinic, $P 2{ }_{1} / n$ & triclinic, $\mathrm{P}-1$ \\
\hline \multirow[t]{6}{*}{ unit cell dimens, $\AA$ and deg } & $a=11.413(5)$ & $a=12.359(5)$ \\
\hline & $b=21.241(5)$ & $b=13.438(5)$ \\
\hline & $c=23.044(5)$ & $c=24.389(5)$ \\
\hline & $\alpha=90.00$ & $\alpha=83.072(5)$ \\
\hline & $\beta=100.773(5)$ & $\beta=81.041(5)$ \\
\hline & $\gamma=90.00$ & $\gamma=64.237(5)$ \\
\hline$V, \AA^{3}$ & $5488(3)$ & $3597(2)$ \\
\hline$Z$; calcd density, $\mathrm{Mg} / \mathrm{m}^{3}$ & $4 ; 1.870$ & $2 ; 1.738$ \\
\hline abs coeff, $\mathrm{mm}^{-1}$ & 3.306 & 3.031 \\
\hline$F(000)$ & 3064 & 1876 \\
\hline cryst size, $\mathrm{mm}$ & $0.10 \times 0.15 \times 0.30$ & $0.15 \times 0.18 \times 0.30$ \\
\hline$\theta$ range for data collcn, deg & $1.31-25.00$ & $0.85-29.10$ \\
\hline limiting indices & $-15 \leq \mathrm{h} \leq 15,-27 \leq \mathrm{k} \leq 28,-31 \leq 1 \leq 30$ & $-16 \leq \mathrm{h} \leq 15,-18 \leq \mathrm{k} \leq 18,-32 \leq \lambda \leq 31$ \\
\hline Reflections collected/unique & $61243 / 13769[\mathrm{R}(\mathrm{int})=0.0593]$ & 49 587/17 $419[\mathrm{R}(\mathrm{int})=0.1078]$ \\
\hline completeness to $\theta=29.00^{\circ}, \%$ & 91.9 & 90.3 \\
\hline abs corr & Sadabs & Sadabs \\
\hline refinement method & full-matrix least squares on $F^{2}$ & full-matrix least squares on $F^{2}$ \\
\hline data/restraints/params & $13769 / 0 / 599$ & $17419 / 70 / 816$ \\
\hline goodness-of-fit on $F^{2}$ & 1.007 & 0.941 \\
\hline final $R$ indices $[I>2 \sigma(I)]$ & $\mathrm{R} 1=0.0628, \mathrm{wR} 2=0.1332$ & $\mathrm{R} 1=0.0610, \mathrm{wR} 2=0.1251$ \\
\hline $\mathrm{R}$ indices (all data) & $\mathrm{R} 1=0.1242, \mathrm{wR} 2=0.1532$ & $\mathrm{R} 1=0.1667, \mathrm{wR} 2=0.1987$ \\
\hline extinctn coeff & & $0.00167(16)$ \\
\hline largest diff peak and hole, $\mathrm{e} \cdot \AA^{-3}$ & 1.13 and -0.50 & 0.68 and -0.64 \\
\hline
\end{tabular}

a first precipitation with toluene, the subsequent redissolutionprecipitation steps are conducted as above with acetone-hexane to obtain directly the crude $\left[\mathrm{NMe}_{4}\right]_{3}\left[\mathrm{Co}_{11} \mathrm{~N}_{2}(\mathrm{CO})_{21}\right]$. Recrystallyzation is performed by acetone/2-propanol.

(b) As $\mathrm{Cs}^{+}-\left[\mathrm{N}-\boldsymbol{n}-\mathrm{Bu}_{4}\right]^{+}$Mixed Salt, via the Anion B. The addition of the correct amount of CO needed to obtain anion $\mathbf{B}$ is somewhat critical and must be closely monitored by IR. In a typical preparation, an acetone solution of $\mathrm{Cs}_{4}\left[\mathrm{Co}_{10} \mathrm{~N}_{2}(\mathrm{CO})_{19}\right](812 \mathrm{mg}$, ca. $0.48 \mathrm{mmol}$, in $13 \mathrm{~mL})$ was treated with $\mathrm{CO}(48 \mathrm{~mL}$, ca. 1.9 mmol) in small portions, until complete reaction of the starting tetraanion and appearance of only the bands of $\mathbf{B}$ (1970 s, 1945 $\left.\mathrm{ms}, 1803 \mathrm{~cm}^{-1}\right)$ together with $\left[\mathrm{Co}(\mathrm{CO})_{4}\right]^{-}\left(1890 \mathrm{~cm}^{-1}\right)$. After a filtration to remove a little insoluble precipitate, the clear solution was treated dropwise with $n$-hexane $(20 \mathrm{~mL})$. The mother liquor was discarded, and the tacky residue was shortly vacuum-dried. Redissolution in acetone $(10 \mathrm{~mL})$ yielded a solution of essentially anion $\mathbf{B}$ with minor amounts of tetracarbonylcobaltate. The solution was divided in five $2 \mathrm{~mL}$ portions, and each one was cautiously layered with dilute 2-propanol solutions of salts of different bulky cations (typically containing $4 \mathrm{mg} / \mathrm{mL}$ ), to get metathesis and hopefully crystallization. Particularly, one of these portions treated with $\left(\mathrm{N}-n-\mathrm{Bu}_{4}\right) \mathrm{Br}$ yielded a precipitate with only a few sparse crystals. Recrystallyzation from THF-acetone, cautiously layered with 2-PrOH, gave crystals of the mixed salt $\mathrm{Cs}\left(\mathrm{N}-n-\mathrm{Bu}_{4}\right)_{2}\left[\mathrm{Co}_{11} \mathrm{~N}_{2-}\right.$ $(\mathrm{CO})_{21}$, suitable for the reported X-ray structure.

2. X-ray Crystal Structure Determination of $\left[\mathrm{NMe}_{4}\right]_{3}\left[\mathrm{Co}_{11^{-}}\right.$ $\left.\mathrm{N}_{2}(\mathrm{CO})_{21}\right] \cdot \mathrm{Me}_{2} \mathrm{CO}$ and of $\left[\mathrm{NBu}_{4}\right]_{2} \mathrm{Cs}\left[\mathrm{Co}_{11} \mathrm{~N}_{2}(\mathrm{CO})_{21}\right]$. Crystals were mounted on a glass fiber in air and collected at room temperature on a Siemens SMART CCD area-detector diffractometer. Crystal data are reported in Table 4. Graphite-monochro- matized Mo $\mathrm{K} \alpha(\lambda=0.71073 \AA)$ radiation was used with the generator working at $45 \mathrm{kV}$ and $40 \mathrm{~mA}$. Orientation matrixes were initially obtained from least-squares refinement on ca. 300 reflections measured in three different $\omega$ regions, in the range $0<\theta<$ $23^{\circ}$; cell parameters were optimized on the position, determined after integration, of ca. 8000 reflections. The intensity data were collected within the limits $0<2 \theta<59^{\circ}$ in the full sphere $(\omega$ scan method), with sample-detector distance fixed at 5.0 and $4.0 \mathrm{~cm}$., respectively; 2400 frames ( $30 \mathrm{~s} /$ frame; $\Delta \omega=0.3^{\circ}$ ) were collected. An empirical absorption correction was applied (SADABS $\left.{ }^{24}\right)$. The structures were solved by direct methods (SIR9725) and refined with full-matrix least squares (SHELX9326) on the basis of 13769 and 17419 independent reflections, respectively; anisotropic temperature factors were assigned to all non-hydrogen atoms. Hydrogens were riding on their carbon atoms.

Acknowledgment. The financial support from the MIUR (Cofin 2003) is gratefully acknowledged.

Supporting Information Available: X-ray crystallographic files in CIF format for $\mathbf{4 a}, \mathbf{b}$. This material is available free of charge via the Internet at http://pubs.acs.org.

\section{IC035133A}

(24) Sheldrick, G. M. SADABS; University of Göttingen: Göttingen, Germany, in press.

(25) Altomare, A.; Burla, M. C.; Camalli, M.; Cascarano, G. L.; Giacovazzo, C.; Guagliardi, A.; Moliterni, A. G. G.; Polidori, G.; Spagna, R. J. Appl. Crystallogr. 1999, 32, 115-119.

(26) Sheldrick, G. M. Programs for Crystal Structure Analysis, release $97-$ 2; Institüt für Anorganische Chemie der Universität: Tammanstrasse 4, D-3400 Göttingen, Germany, 1998. 